\title{
Pengembangan olah pangan berbahan baku jagung dan talas bagi kelompok tani desa sungai enau kecamatan kuala mandor
}

\author{
Development of Food aAnd Raw Materials Based on Corn and Talas for Farmer \\ Groups of River Enau Village Sub-Districts Kuala Mandor \\ Desdy Hendra Gunawan ${ }^{1)}$, Ridwan Salim ${ }^{1)}$ \\ ${ }^{1}$ Politeknik Negeri Pontianak, Jurusan Teknologi Pertanian dan Perikanan, Jalan Jenderal \\ Ahmad Yani Pontianak, Kalimantan Barat \\ Informasi Artikel: \\ Dikirim: 30/08/2019; ditinjau: 31/08/2019; disetujui: 29/09/2019
}

\begin{abstract}
Taro and maize are agricultural products that have nutrients, especially fiber, so it is very good to be developed and its presence in the location of the activity is relatively abundant, so that further management is needed. The main objective of the community service activity is to provide guidance for the farmer group in the enau river village in downstreaming the locally owned raw materials in the form of taro and corn into processed products that have high sales value. The achievement is carried out with the theoretical and practical method of transferring appropriate technology accompanied by experts in their fields in the hope of ease of absorption and targeted plans. For convenience in implementing partners, it is divided into several small groups and is responsible for the products proclaimed. The results obtained in the form of 6 products consisting of flour, chips, taro cookies are preferred by all respondents, while cake is only $75 \%$, while products made from corn which include nuggets and $100 \%$ corn donuts are preferred. The product is equipped with packaging that is labeled on each product.
\end{abstract}

Keywords: taro, corn, service, processed products

\begin{abstract}
ABSTRAK
Talas dan jagung merupakan hasil pertanian yang memiliki nutrisi terutama serat sehingga sangat baik untuk dikembangkan dan keberadaanya di lokasi kegiatan terbilang melimpah, sehingga sangat diperlukan penanganan lanjutan. Tujuan utama kegiatan pengabdian adalah melakukan pembinaan bagi kelompok tani desa sungai enau dalam melakukan hilirisasi bahan baku lokal yang dimiliki berupa talas dan jagung menjadi olahan produk yang memiliki nilai jual tinggi. Pada pencapainnya dilakukan dengan metoda transfer teknologi tepat guna secara teoritis dan praktis yang didampingi oleh pakar dibidangnya dengan harapan kemudahan dalam penyerapan dan rencana yang ditargetkan. Untuk kemudahan dalam pelaksanaan mitra dibagi dalam beberapa kelompok kecil dan bertangung jawab atas produk yang dicanangkan. Hasil yang diperoleh berupa 6 produk yang terdiri dari tepung, chip, cookies talas disukai oleh seluruh responden, sedangkan cake hanyak $75 \%$, sedangkan produk berbahan jagung yang meliputi nugget dan donat jagung 100\% disukai. Produk tersebut dilengkapi dengan pengemasan yang diberi label pada masing-masing produk.
\end{abstract}

Kata Kunci: talas, jagung, pengabdian, olahan produk 


\section{PENDAHULUAN}

Desa Sungai Enau merupakan satu desa yang berlokasi diwilayah Kecamatan Mandor Kabupaten Kubu Raya Kalimantan Barat.Desa ini merupakan desa pesisir yang terletak dipinggir sungai yang berbatasan langsung dengan Kabupaten Landak. Luas Wilayah Desa Sungai Enau berkisar +78.365.39 $\mathrm{km}^{2}$, dengan sebagian besar wilayahnya $20 \%$ yang belum dikelolah/ hutan lindung, 35\% dipergunakan untuk pemukiman dan $45 \%$ untuk perkebunan dan lahan pertanian.Jarak desa dengan Politeknik Negeri Pontianak adalah 40 KM dapat ditempuh dengan jalan darat, namun dibagian tertentu dari wilayahnya dapat juga ditempuh dengan jalan air (menggunakan sampan atau speedboat).Wilayah Desa Sungai Enau dilintasi garis khatulistiwa beriklim tropis, terletak pada ketinggian $3 \mathrm{~m}$ dari permukaan laut dengan suhu rata-rata $25^{\circ} \mathrm{C}$, dengan iklim dua musim yaitu musim hujan dan kemarau. Jumlah penduduk tercatat pada tahun 2015 berjumlah 5234 jiwa dengan pembagian penduduk laki-laki berjumlah 2597 jiwa dan perempuan 2639 jiwa dengan jumlah kepala keluarga sebanyak 1.503 kepala keluarga (KK) (Profil Desa Sungai Enau, 2017).

Berdasarkan data demografi, wilayah desa ini memiliki pembagian wilayah sebagai berikut: sebelah timur berbataskan dengan Sungai Desa Retok, sebelah barat berbatasan dengan desa sungai Malaya, sebelah Utara berbatasan dengan Desa Kubu Padi dan sebelah Selatan berbatasan dengan desa kuala mandor. Perekonomian desa Sungai Enau diantaranya bertumpu pada sektor pertanian dan perkebunan. Tanaman yang diusahakan meliputi: karet, sawit, keladi, pisang, cabai, jengkol, jagung, padi, ubi kayu dan sayur. Namun tanaman jangka pendek yang paling dominan adalah talas dan jagung, namun masyarakat setempat memperoleh keuntungan yang sangat minim karena pendistribusian hasil pertanian dan perkebunan dalam bentuk segar tanpa kreasi olahan walaupun minimal. Realita ini menjadikan dasar dalam perbaikan ekonomi, walaupun dalam tahap awal sangatlah sulit dan keuntungan yang diperoleh belum terbilang memuaskan, namun jika dilakukan sentuhan teknologi olah produksi dan kemasan, maka produk dengan bahan baku yang dimaksud memiliki peluang yang sangat menjanjikan.

Menurut Koswara (2008), umbi talas yang sudah dipanen mudah rusak, talas yang sudah terlanjur dipanen tidak bisa bertahan lama tanpa pengolahan dan bila kita ingin menyimpan umbi selamabeberapa waktu lamanya kita harus menjaganya dari kerusakan mekanis dan diusahakan ruang pen yimpanan tetap kering. Diketahui umbi talas merupakan bahan pangan yang memiliki nilai gizi yang cukup baik. Talas (Colocasia esculenta L. Schott) adalah kanji umbi yang banyak tumbuh di daerah tropis tersebut sebagai Indonesia. Negara-negara Asia berkontribusi $32 \%$ dari total produksi dunia (Arici et al., 2016). Talas memiliki tinggi manfaat nutrisi seperti indeks glikemik sedang dan antioksidan tinggi (Simsek dan El, 2015), mudah dicerna (Sefa-Dedeh dan AgyirSackey, 2002), berserat, sertan memiliki kandungan protein, vitamin, fosfor,dan kalsium (Sefa-Dedeh dan Agyir-Sackey, 2004).

Tepung talas biasanya digunakan sebagai bahan mentah bahan untuk kue dan makanan ringan (Elisabeth, 2015). Talas tepung dapat diubah menjadi berbagai produk akhir dengan nilai ekonomi terutama untuk skala kecil dan menengah perusahaan makanan dan minuman. Aboubakar, Scher dan Mbofung (2008) meneliti fisikokimia dan termal properti serta mikrostruktur enam varietas tepung dan tepung talas. Kaushal, Kumar dan Sharma (2012) menyatakan bahwa tepung talas memiliki kandungan yang potensial untuk digunakan dalam industri makanan.

Sama halnya dengan jagung yang memiliki nutrisi penting yang dapat dimanfaatkan untuk pemenuhan metabolism tubuh. Jagung mengandung sejumlah protein, serat kasar, gula, lemak dan pati yang berada pada endocarp, pericarp dan embrio, sehingga penggunaan jagung secara keseluruhan akan memperoleh kuantitas yang maksimal (Anonym, 2008). Jagung menurut Suarni (2009) termasuk tanaman serealia mengandung banyak serat pangan yang populer diteliti potensi kandungan unsur pangan fungsionalnya. Komponen utama 
jagung adalah pati yaitu sekitar $70 \%$ dari bobot biji, komponen. Ullah et al.,(2010)menyebutkan bahwa jagung merupakan penghasil karbohidrat setelah beras dan juga mengandung protein tinggi (7-12\%), sehingga dapat dijadikan sumber protein, selain itu menurut Koswara (2009) biji jagung mengandung mineral potassium $0,40 \%$, phosfor $0,43 \%$, magnesium $0,16 \%$, sulfur $0,14 \%$ dan mineral-mineral lain $0,27 \%$, sehingga memiliki peran dalam pangan.

Jagung dipilih karena selama ini pemanfaatan bekatul masih terbatas untuk pangan, padahal kandungan gizinya dapat dimanfaatkan dalam mengembangkan suatu produk food bar (Kusumastuty, Fandianty dan Julia, 2015). Jagung kaya akan komponen pangan fungsional, termasuk serat pangan yang dibutuhkan tubuh, asam lemak esensial, isoflavon, mineral $(\mathrm{Ca}, \mathrm{Mg}, \mathrm{K}, \mathrm{Na}, \mathrm{P}, \mathrm{Ca}$ dan $\mathrm{Fe}$ ), antosianin, betakaroten (provitamin $\mathrm{A}$ ), komposisi asam amino esensial, dan lainnya (Suarni dan Yasin, 2015). Pengolahan jagung menjadi pati mempunyai prospek untuk meningkatkan nilai tambah jagung (Suarni, Firmansyah dan Aqil, 2015).

Tepung jagung memiliki kadar air $7,68 \%$, kadar abu $0,27 \%$, kadar protein terlarut $2,48 \%$, protein total $8,27 \%$, kadar amilosa $33,10 \%$, kapasitas penyerapan air 117,80\%, kapasitas penyerapan minyak $149,50 \%$, dan swelling power $13,80 \%$ (aini, Wijonarko dan Sustriawan, 2016). Viskositas maksimal tepung jagung termodifikasi yang rendah diharapkan lebih memudahkan aplikasinya pada produk pangan (Yuan et al., 2008). Tepung jagung merupakan sumber bahan pangan yang potensial untuk diolah menjadi mi jagung kering (Kusnandar et al., 2018). Penggunaan bahan pengisi tepung jagung Provit A1 dengan taraf $10 \% \quad\left(\begin{array}{lll}40 & \mathrm{~g}\end{array}\right)$ memberikan hasil nugget ayam kampung dengan karakteristik kualitas nugget ayam kampung yang terbaik (Ma'ruf et al., 2019).

Permasalahan yang dimiliki mitra telah diungkapkan yaitu dimilikinya limpahan sumber daya alam lokal yang di barengi dengan ketersediaan sumber daya manusia yang memiliki semangat perubahan, namun membutuhkan pendampingan dari segmen peningkatan keterampilan menjadikan masalah yang terbilang komplek dan disepakati bersama untuk diberikan solusinya, namun harus diatasi sesegera mungkin untuk mencapai kelompok mitra yang produktif dan mandiri.

\section{METODA PELAKSANAAN}

Kegiatan Pengabdian masyarakat ini dilakukan Kantor Desa Sungai Enau , hal ini dimaksudkan agar semua peserta dapat dengan mudah berkumpul untuk kegiatan yang dimaksud. Kegiatan ini dihadiri 1 mitra yang ditunjuk dengan jumlah peserta 15 orang.

Bahan yang digunakan dalam pengolahan aneka produk makanan terdiri dari talas dan jagung yang kami peroleh dari warga setempat, sedangkan bahan-bahan untuk pembuatan produk yaitu: 1) Tepung talas : talas, garam, abu gosok, air, 2) cookies : tepung talas, gula garam, telur, bahan toping, margarine, susu bubuk, kental manis, garam, maezena, baking powder. 3) cake talas: tepung talas, gula garam, telur, bahan toping, margarine, susu bubuk, kental manis, garam, butter 4) chip talas : talas, gula, garam, abu gosok, bumbu aneka rasa, minyak goreng. 5) Nugget jagung: jagung, telur, margarine, bumbu-bumbu, roti tawar, ayam, daging, udang, terigu, panir, garam, gula, minyak goring.

Alat yang digunakan untuk pengolahan produk meliputi: panci perebusan,pengukus, sendok, gelas plastic, kompor gas, baskom bolong,oven, blender, mixer, seller, pisau, timbangan, sutil, wadah kemas, baskom besar baskom keci, plastic kemasan, wajan, plasik PE,spatula, serbet, tissue, teko ukur, cetakan kue, kertas minyak, nampan, tabung gas.

Aspek Proses Produksi Olahan.

\section{Tepung Talas}

Talas dikupas dan direndam 1 jam dengan air mengalir. Hasil perendaman ditiriskan dan dijemur dibawah terik matahari selama 1 minggu Lakukan penepungan menggunakan hammermill dan diayak dengan saringan 80 mesh.

\section{Cake Talas}

Tepung talas yang sudah diayak kemudian dijemur kembali.Siapkan margarine, telur, gula halus, mentega caping untuk selanjutnya di mixer hingga mengembang. Tambahkan 
tepung talas dan tepung terigu dan diuleni hingga kalis. Lakukan pencetakan dan tambahkan bahan lainnya untuk memperindah tampilan cake Panggang dengan suhu $145^{\circ} \mathrm{C}$ selama 45 menit setelah dingin gambahkan toping Masukkan platsik dan toples

\section{Chips Talas}

Siapkan talas bersihkan dan dipotong memanjang lalu rendam dengan air garam Lanjutkan dengan perendaman larutan gula selama 1 jam, kemudian tiriskan. Buat adonan telur, margarine untuk mencelupkan potongan talas.Lakukan penggorengan hingga chips matangSetelah dingin tambahkan taburan toping yang disediakan untuk meningkatkan rasaMasukkan dalam plastik dan toples untk selanjutnya diberikan pelabelan

\section{Nugget jagung}

Jagung manis direbus kemudian dipipil dan dihancurkan. Tambahkan bumbu halus seperti bawang merah,bawang putih, merica,ketumbar. Tambahkan telur, terigu dan merica, garam,gula dan bubuk pala. Adonan $\mathrm{a}, \mathrm{b}$ dan $\mathrm{c}$ dijadikan satu kemudian dikukus dan cetakLakukan pengulangan untuk semua jenis daging yang digunakan.Celupkan kedalam telur dan gulingkan diatas tepung roti.Goreng hingga kuning keemasan

\section{Donat Jagung}

Siapkan jagung pipil untuk selanjutnya dikukus selama 20 menit dan haluskan Tambahkan bahan terigu, fermipan, butter, margarine, telur dan baking powderUleni adonan menjadi satu sampai kalis dan biarkan selama 1 jamSetelah itu bentuk menjadi adonan donat dan biarkan selama 30 menit. Lakukan penggorengan dan berikan toping yang disediakan dan pelabelan

\section{HASIL DAN PEMBAHASAN}

Hasil produk yang dihasilkan, kemudian dilakukan uji penerimaan konsumen terbatas pada seluruh peserta pelatihan dengan jumlah responden 15 orang. Hasil yang diperoleh terhadap olahan produk disajikan pada Tabel 1.

Tabel 1. Olahan produk talas dan jagung

\begin{tabular}{ccc}
\hline \multirow{2}{*}{ Nama Produk } & \multicolumn{2}{c}{ Penilaian Konsumen } \\
\cline { 2 - 3 } & Menerima & Tidak Menerima \\
\hline Tepung & 15 & 0 \\
Chip & 12 & 3 \\
Cookies & 15 & 0 \\
Cake & 10 & 5 \\
Nugget & 15 & 0 \\
Donat & 15 & 0 \\
\hline
\end{tabular}

Sumber data: Kuisioner kegiatan PKM 2019 Desa Sungai Enau

\section{Produk Tepung}

Produk tepung berbahan baku talas, menyimpulkan bahwa sebanyak semua responden yang berjumlah 15 orang dapat menerima dengan baik, artinya semua responden menyukai secara keseluruhan baik dari segi bentuk, warna dan metoda yang digunakan dalam perwujudannya. Tepung yang dihasilkan memiliki warna ungu dan tekstur halus, sehingga membuat responden dapat merasakan sensasi talas aslinya.

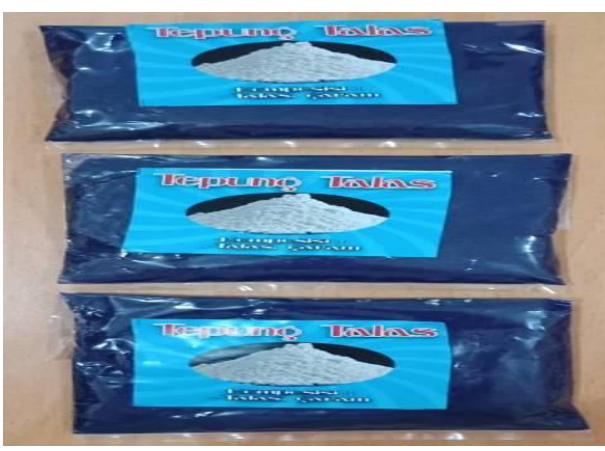

Gambar 1.Tepung talas

\section{Chip Talas}

Produk chip berbahan baku talas, menyimpulkan bahwa sebanyak 12 orang menerima dalam arti responden menyukai dalam hal rasa yang beraneka, tekstur renyah, 
tampilan yang menarik, sedangkan responden yang tidak menyukai sebanyak 3 orang dengan alasan metoda yang digunakan tidak umum yaitu merendam bahan dengan menggunakan abu gosok dan dianggap pemborosan bahan sehingga tidak efisien. Abu gosok berdasarkan penelitian dapat mengikat senyawa oksalat yang terdapat pada bahan sehingga dapat mengurangi rasa gatal dan serta lender. Asam oksalat adalah senyawa kimia yang memiliki rumus $\mathrm{H} 2 \mathrm{C} 2 \mathrm{O} 4$ dengan nama sistematis asam etanadioat yang merupakan asam organik kuat (Kirk, 2007).

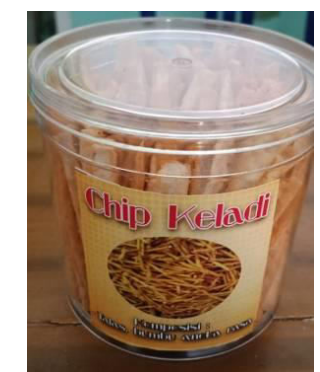

Gambar 2.Chip talas

\section{Cookies Talas}

Cookies talas yang dihasilkan memberikan respon keseluruhan dari responden menyatakan suka dari sisi warna, rasa, tekstur dan tampilan yang sangat menarik. Warna yang digunakan memang bukan warna asli dari bahan melainkan dengan memvariasikan warna lain seperti ungu. Selain itu pemberian topping pada bagian atasnya menjadikan produk ini lebiih menarik dan memiliki daya tarik tersendiri.

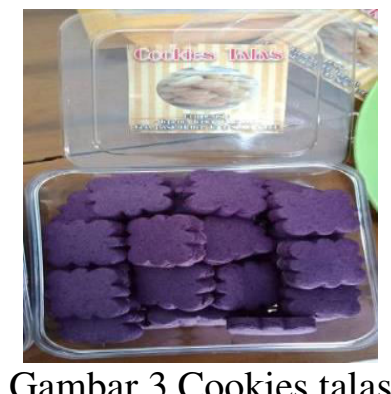

\section{Pengolahan Cake}

Tidak semua responden menyukai produk ini, terdapat 12 responden yang menyukai sedangka 3 responden lainnya tidak menyukai. Penerimaan responden yang suka terhadap produk ini disebabkan karena tekstur yang lembut dan tidak kalah dengan cake yang dibuat dari terigu, sehingga mereka menganggap baha ini adalah inovasi produk yang sangat menarik dikembangkan, sedangkan ketidaktertarikan respoden disebabkan karena bahan pembantu lainnya terbilang mahal. Namun pada hakikatnya bahan pembantu dapat dikurangi porsinya.

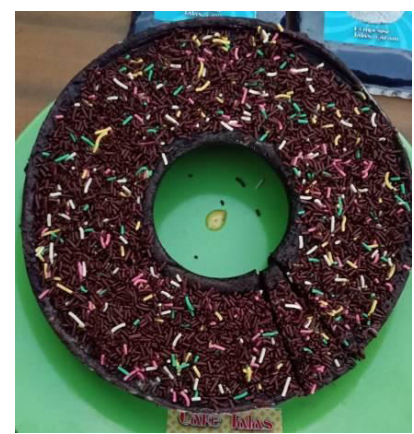

Gambar 4.Cake talas

\section{Nugget Jagung}

Selain cookies yang menjadi produk unggulan, nugget jagung juga merupakan salah satu produk yang sangat digemari, karena rasa, bentuk dan sensasi khas jagung yang dapat dirasakan. Bahan-bahan segar dan bumbu yang digunakan menambah cita rasa dari nugget yang dihasilkan.

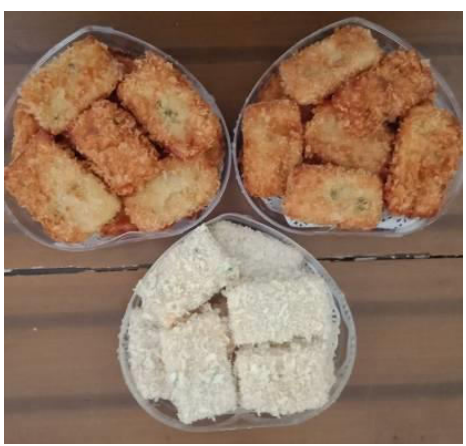

Gambar 5.Nugget jagung

\section{Donat Jagung}

Produk terakhir berupa dari jagung.Umumnya donat dibuat dari terigu, kentang dan ubi jalar. Pengenalan pembuatan donat dari jagung menjadikan produk ini sebagai primadona baru. Hal ini dibuktikan dengan jumlah responden yang menyukainya lebih banyak dari sebaliknya. 


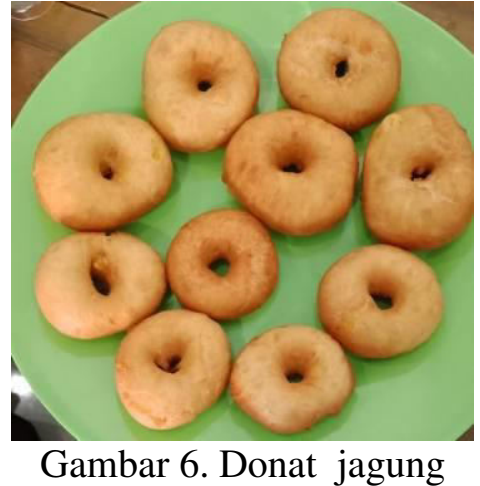

\section{KESIMPULAN}

1. Mitra telah memperoleh informasi dan keterampilan, keahlian serta kemampuan dalam mengolah talas dan jagung menjadi produk olah pangan yang keratif dan inovatif.

2. Semua produk yang diciptakan disukai oleh konsumen.

\section{UCAPAN TERIMKASIH}

Ucapan terimakasih kami tujukan kepada KEMENRISTEKDIKTI yang telah membiayai seluruh kegiatan pengabdian masyarakat tahun anggaran 2019 dan kepada mitra Desa Sungai Enau atas waktu, kemauan dan semangatnya untuk maju bersama.

\section{DAFTAR PUSTAKA}

Aboubakar, N. Y., Scher, J., \& Mbofung, C. M. F. (2008). Physicochemical, thermal properties and microstructure of six varieties of taro (Colocasia esculenta L. Schott) flours and starches. Journal of Food Engineering, 86(2), 294-305.

Aini, N., Wijonarko, G., \& Sustriawan, B. (2016). Sifat fisik, kimia, dan fungsional tepung jagung yang diproses melalui fermentasi. Agritech, 36(2), 160-169.

Anonimus. (2017). Profil desa sungai enau, Kabupaten Kubu Raya, Kalimantan Barat.

Anonymus. (2008).The biology of Zea mays L.ssp. mays (Maize or corn). Australian Government. Departement of Healt and
Ageing Office of The Gene Technology Regulator. Version 1; September 2008.

Arıcı, M., Yıldırım, R. M., Özülkü, G., Yaşar, B., \& Toker, O. S. (2016). Physicochemical and nutritional properties of taro (Colocasia esculenta L. Schott) flour as affected by drying temperature and air velocity. $L W T, 74$, 434-440.

Elisabeth, D. A. A. (2015). Added value improvement of taro and sweet potato commodities by doing snack processing activity. Procedia Food Science, 3, 262-273.

Kaushal, P., Kumar, V., \& Sharma, H. K. (2012). Comparative study of physicochemical, functional, antinutritional and pasting properties of taro (Colocasia esculenta), rice (Oryza sativa) flour, pigeonpea (Cajanus cajan) flour and their blends. LWT-Food Science and Technology, 48(1), 59-68..

Koswara, S. (2008). Modul teknologi pengolahan umbi-umbian, Bagian 1: Pengolahan umbi talas. Southeast Asian Food And Agricultural Science and Technology (SEAFAST) Center Research and Community Service Institution. Bogor Agricultural University. Retrived from: http://seafast.ipb.ac.id.

Koswara, S. (2009). Teknologi pengolahan jagung (teori dan praktek). eBookPangan.com 2009

Kusnandar, F., Palupi, N. S., Lestari, O. A., \& Widowati, S. (2018). Karakterisasi tepung jagung termodifikasi heat moisture treatment (HMT) dan pengaruhnya terhadap mutu pemasakan dan sensori mi jagung kering. Jurnal Penelitian Pascapanen Pertanian, 6(2), 76-84.

Kusumastuty, I., Fandianty, L., \& Julia, A. R. (2015). Formulasi food bar tepung bekatul dan tepung jagung sebagai Pangan darurat. Indonesian Journal of Human Nutrition, 2(2), 68-75.

Ma'ruf, W., Rosyidi, D., Radiati, L. E., \& Purwadi, P. (2019). Pengaruh Jenis 
dan Proporsi Penggunaan Tepung Jagung Terhadap Daya Ikat Air dan Kualitas Organoleptik dari Nugget Ayam Kampung. Jurnal Ilmu dan Teknologi Hasil Ternak (JITEK), 14(1), 38-49.

Njintang, Y. N., Scher, J., \& Mbofung, C. M. F. (2008). Physicochemical, thermal properties and microstructure of six varieties of taro (Colocasia esculenta L. Schott) flours and starches. Journal of Food Engineering, 86(2), 294-305.

Sefa-Dedeh, S., \& Agyir-Sackey, E. K. (2004). Chemical composition and the effect of processing on oxalate content of cocoyam Xanthosoma sagittifolium and Colocasia esculenta cormels. Food Chemistry, 85(4), 479-487.

Sefa-Dedeh, S., \& Sackey, E. K. A. (2002). Starch structure and some properties of cocoyam (Xanthosoma sagittifolium and Colocasia esculenta) starch and raphides. Food Chemistry, 79(4), 435444..

Simsek, S., \& El, S. N. (2015). In vitro starch digestibility, estimated glycemic index and antioxidant potential of taro
(Colocasia esculenta L. Schott) corm. Food Chemistry, 168, 257-261.

Suarni, M., Aqil, \& Firmansyah. I.U. (2008). Effect of drying temperature on nutritional quality of protein maize. Proceeding of The10th Asian Regional Maize Workshop (ARMW).p.79-81.

Suarni, S., \& Yasin, M. (2015). Jagung sebagai sumber pangan fungsional. Iptek Tanaman Pangan, 6(1), 41-56.

Suarni, S., Firmansyah, I. U., \& Aqil, M. (2015). Keragaman mutu pati beberapa varietas jagung. Jurnal Penelitian Pertanian Tanaman Pangan, 32(1), 50-56.

Ullah, L., Ali, M., \& Farooqi, A. (2010). Chemical and nutritional properties of corn maize varieties grown in nwfp pakistan. Journal of Nutrition, 9, 11131117.

Yuan, M.L., Lu, Z.H., Cheng, Y.Q., \& Li, L.T. (2008). Effect of spontaneous fermentation on the physical properties of corn starch and rheological characteristics of corn starch noodle. Journal of Food Engineering, 85(1), 12-17. 